\title{
PENGARUH PERCEIVED QUALITY DAN PERCEIVED VALUE TERHADAP PURCHASE INTENTION DIMEDIASI PERCEIVED RISK
}

\author{
Carolus Mario Nanjaya dan Andi Wijaya \\ Program Studi Manajemen, Fakultas Ekonomi Universitas Tarumanagara, Jakarta \\ Email : marionanjaya07@gmail.com
}

\begin{abstract}
The global economy is something that must always be considered. The growing economy and the increasing number of competitors, make various parties have to rack their brains so that their companies are not left behind and continue to lead. The purpose of this study was to determine the effect of perceived quality and perceived value on purchase intention mediated by perceived risk. This research method uses quantitative methods using 100 samples taken from buyers of OFFBEAT \& CO products, this study uses a Likert scale and analysis using PLS as a tool in data processing. The results of this study indicate that perceived value, perceived quality and perceived risk have a positive and significant effect on purchase intention.
\end{abstract}

Keywords: perceived value, perceived quality dan perceived risk, purchase intention.

Abstrak: Sumber Perekonomian global merupakan sesuatu yang harus selalu diperhatikan.Perekonomian yang semakin berkembang dan saingan yang menjadi semakin banyak, membuat berbagai pihak harus memutar otak agar perusahaannya tidak tertinggal dan terus memimpin. Tujuan penelitian ini adalah untuk mengetahui pengaruh perceived quality dan perceived value terhadap purchase intention yang dimediasi perceived risk. Metode penelitian ini menggunakan metode kuantitatif dengan menggunakan sampel yang berjumlah 100 yang diambil dari para pembeli produk OFFBEAT \& CO, penelitian ini menggunakan skala likert dan analisis menggunakan PLS sebagai alat bantu dalam melakukan pengolahan data. Hasil penelitian dari penelitian ini menunjukkan bahwa perceived value, perceived quality dan perceived risk berpengaruh positif dan signifikan terhadap purchase intention.

Kata kunci: perceived value, perceived quality dan perceived risk, purchase intention.

\section{LATAR BELAKANG}

Perekonomian global merupakan sesuatu yang harus selalu diperhatikan.Perekonomian yang semakin berkembang dan saingan yang menjadi semakin banyak, membuat berbagai pihak harus memutar otak agar perusahaannya tidak tertinggal dan terus memimpin. Peekonomian global saat ini dikuasai sebagian besar oleh Amerika dan juga China yang menerbitkan perang pasar, hal tersebut membuat perekonomian di dunia menjadi sedikit goyah.

Konsumen merupakan seseorang yang memegang peranan yang terbesar di dalam pertumbuhan ekonomi dikarenakan dengan semakin banyaknya jumlah konsumen atau pembeli, maka perekonomian akan semakin berjalan dan tentunya penghasilan dari suatu produk tersebut akan semakin tinggi dan maju. Hal itu menyebabkan perusahaan harus dapat mencari cara agak para pelanggan membeli produk dan barang yang mereka jual dan buat. 
Terdapat beberapaa hal yang dapat berpengaruh seperti perceived value dan perceived intention.Dengan demikian kualitas jasa (service quality) dapat diartikan seberapa jauh perbedaan antara kenyataan dengan harapan pelanggan atas layanan yang mereka terima/peroleh (Lupiyoadi, 2001).

Persaingan bisnis saat ini telah mendorong para pengelola bisnis untuk bergerak cepat, kreatif dan antisipatif. Hal ini disebabkan oleh perubahan mendasar dalam sistem persaingan bisnis yang memanfaatkan teknologi. Perubahan tersebut meliputi sistem perdagangan, cara bertransaksi, sistem pemasaran maupun sistem pembayaran. Cara mengenalkan produkpun sekarang ini cenderung menggunakan metode direct marketing yang memang telah didukung oleh teknologi informasi yang super canggih. Produk dengan cepat dapat ditawarkan kepada para prospective buyer langsung ke meja mereka. Ini dikarenakan pengomunikasian produk sekarang sudah menggunakan media teknologi informasi terutama media internet yang langsung ke para pembeli potensial (Henry, 2017).

Industri kreatif memiliki peran penting dalam pertumbuhan ekonomi di Indonesia. Badan Pusat Statistik (BPS) tahun 2013 menyatakan, pertumbuhan industri kreatif mencapai 7,6 persen dan menghasilkan Rp 641,82 triliun. Hal tersebut menunjukkan, industri kreatif memberikan pengaruh pada kenaikan Gross Domestic Product (GDP) Indonesia. Potensi industri ini diharapkan terus tumbuh, seperti tertera dalam blueprint industri kreatif Indonesia. Industri ini ditargetkan memberi kontribusi 11-12\% GDP pada 2025 (Hendrayati \& Gaffar, 2016).

\section{KAJIAN TEORI}

\section{Gambaran Umum Teori}

Kualitas yang dirasakan juga mempengaruhi persepsi nilai kepada pelanggan. Dengan menyediakan merek sebagai suatu alasan untuk membeli dan menjadi faktor pembeda dengan merek lain. Perceived value juga didasarkan pada perbedaan antara apa yang di dapatkan pelanggan dan apa yang di korbankan untuk berbagai kemungkinan pilihan. Perceived quality memiliki pengaruh terhadap perceived value berdasarkan kualitas dan nilai dari suatu produk yang dikonsumsi oleh pelanggan. Semakin tinggi kualitas yang diberikan dari suatu produk maka nilai yang terkandung juga semakin tinggi sehingga pelanggan merasa terpenuhi akan keinginan serta kebutuhannya.

Milfelner (2017) mengungkapkan bahwa konsep dari perceived quality dan perceived value memiliki persamaan. Namun pemerataan konsep tersebut dianggap sama, karena nilai yang dirasakan telah terbukti menjadi konsep multidimensi dari manfaat dan pengorbanan yang dirasakan oleh pelanggan (Milfelner, 2017). Disisi lainperceived quality didefinisikan sebagai penilaian pelanggan tentang entitas keseluruhan dari keunggulan suatu produk (Milfelner, 2017). Oleh karena itu, jika kualitas adalah salah satu manfaat utama yang dicari pelanggan maka itu tidak sama dengan nilai.

Milfelner (2017) menjelaskan hubungan antara persepsi kualitas dengan persepsi nilai yang dirasakan. Menunjukkan bahwa persepsi kualitas yang lebih tinggi biasanya mengarah ke nilai yang dirasakan lebih tinggi. Milfelner (2017) juga berpendapat bahwa kualitas bukan harga adalah penentu utama dari nilai yang dirasakan untuk suatu produk maupun jasa. Petrick (2018) menyatakan bahwa persepsi kualitas yang lebih tinggi dapat meningkatkan nilai yang dirasakan pelanggan terhadap suatu produk.

Pelanggan dengan niat untuk membeli didorong oleh perceived quality yang dirasakan merupakan akibat langsung dari kualitas atau keuntungan yang diperoleh pelanggan (Zeithmal 1988 dalam Khan, 2017). Kualitas yang dijanjikan dari suatu merek akan mempengaruhi 
persepsi pelanggan untuk membuat keputusan pada pembelian berikutnya. Semakin kuat maksud atau keinginan seseorang uentuk melakukan pembelian ulang, maka akan semakin besar kemungkinan pelanggan tersebut akan melakukannya. Persepsi kualitas adalah nilai tambah dari suatu produk (Bhuan, 1997 dalam Khan, 2017). Jika kualitas tinggi yang dirasakan dari produk, pelanggan akan lebih cenderung untuk membeli. Dalam melakukan bisnis apapun, pelaku bisnis mengharapkan bisnis tersebut dapat bertahan lama. Salah satu faktor penting dalam mewujudkannya adalah membangun minat pembelian pelanggan (Keni, 2020).

Perceived value merupakan sebuah pemikiran yang dilakukan oleh pihak konsumen atau pembeli yang berguna sebagai pembanding atau pemikiran mereka mengenai nilai yang ada di dalam sebuah produk (Hellier, 2003; Spais, 2018). Diketahui bahwa di dalam sebuah pembelian, seseorang akan melakukan mengenai pemikiran yang berhubungan mengenai nilai yang berlaku di dalam sebuah produk atay jasa. perceived value yang lebih tinggi membuat niat beli yang lebih tinggi semakin banyak value yang dirasakan, konsumen akan melakukan pembelian lagi (Keni, 2020).

Perceived quality merupakan sebuah pemikiran yang berasal dari konsumen atau pembeli yang digunakan oleh mereka untuk melihat apakah kualitas barang ini sesuai dengan yang mereka butuhkan ataukah sesuai dengan hrapan mereka. Hellier (2019). Perceived quality diketahui menjadi salah satu faktor yang menjadikan seseorang membeli sebuah produk

Purchase intention pembelian merupakan bagian akhir dari proses pembelia yang berlangsung dari berbagai macam proses. Pembelian yang dibeli oleh seseorang didasarkan pada kebuthan yang ada dan keinginan. Pembelian sebuah barang merupakan sebuah proses yang berlangsung panjang yang akan membuat seseorang berfikir dan berpersepsi mengenai barang atau jasa yang dibutuhkan.

\section{Definisi Konseptual Variabel}

1. Perceived quality

Perceived quality adalah sebuah pemikiran dari seseorang mengenai kualitas barang atau jasa yang akan mereka gunakan (Xu, 2018). Persepsi kualitas adalah sebuah nilai yang ditonjolkan sebagai nilai tambah dari suaatu produk (Khan, 2017). Spais (2017) mendefinisi perceived quality sebagai penilaian konsumen secara keseluruhan terhadap atribut produk

2. Perceived value

Penilaian seseorang individu mengenai nilai dari sebuah barang apakah sesuai atau tidak (Kassim, 2017). Menurut Canon (2018) perceived value adalah pemikiran mengenai sebuah nilai yang dilihat dari sebuah barang atau jasa. Perceived value adalah penilaian konsumen mengenai jasa yang telah diberikan dengan mempertimbangkan manfaat dari apa yang telah di keluarkan (Kurniawan, 2017).

3. Perceived risk

Featherman (2017) mendefinisikan perceived risk sebagai ketidakpastian mengenai konsekuensi negatif yang mungkin terjadi dari penggunaan produk atau jasa. Persepsi risiko didefinisi sebagai ketidakpastian yang dihadapi oleh para konsumen ketika mereka tidak dapat memprediksi konsekuensi keputusan pembelian mereka (Schiffman, 2018). Perceived risk adalah konsekuensi yang akan diterima ketika menggunakan suatu produk atau jasa yang tidak sesuai dengan yang diharapkan dari suatu pilihan tertentu (Wulandari, 2017).

4. Purchase intention

Niat untuk membeli merupakan sebuah kemungkinan yang terjadi di dalam sebuah proses transaksi untuk membeli barng atau jasa tersebut (Mahmoudzadeh, 2014). Niat beli merupakan sebuah kecenderungan untuk memiliki produk tertentu (Chi, et al., 2017). Shah 
et al. (2018) menunjukkan bahwa niat beli adalah jenis pengambilan keputusan mengenai alasan mengapa pelanggan cenderung membeli merek tertentu. Purchase Intention adalah sesuatu hal yang mewakili konsumen yang mempunyai kemungkinan, akan, rencana atau bersedia untuk membeli suatu produk atau layanan di masa depan. Peningkatan niat pembelian ini berarti peningkatan kemungkinan pembelian (Schiffman, 2018)

Hubungan antara perceived quality dengan purchase intention

Berdasarkan penelitian yang dilakukan oleh Saputri (2018) mendapatkan hasil terdapat pengaruh positif perceived quality terhadap purchase intention. Berdasarkan penelitian yang dilakukan oleh Wendyanto (2017) mendapatkan hasil bahwa perceived quality berpengaruh positif terhadap purchase intention. Berdasarkan penelitian yang dilakukan oleh Kurniawan (2018) mendapatkan hasil bahwa perceived quality berpengaruh positif terhadap purchase intention.

Hubungan antara perceived value terhadap purchase intention

Berdasarkan penelitian yang dilakukan oleh Saputri (2018) mendapatkan hasil terdapat pengaruh positif perceived value terhadap purchase intention. Berdasarkan penelitian yang dilakukan oleh Wendyanto (2017) mendapatkan hasil bahwa perceived value berpengaruh positif terhadap purchase intention. Berdasarkan penelitian yang dilakukan oleh Kurniawan (2018) mendapatkan hasil bahwa perceived value berpengaruh positif terhadap purchase intention

Hubungan antara perceived risk terhadap purchase intention

Berdasarkan penelitian yang dilakukan oleh Rejeki (2017) didapatkan hasil bahwa perceived risk berpengaruh terhadap purchase intention. Berdasarkan penelitian yang dilakukan oleh Henry (2017) didapatkan hasil bahwa perceived risk ebrpengaruh terhadap purchase intention. Berdasarkan penelitian yang dilakukan oleh Kurniawan (2018) mendapatkan hasil bahwa perceived risk berpengaruh positif terhadap purchase intention.

H1. Perceived quality berpengaruh positif terhadap perceived risk

H2. Perceived value berpengaruh positif terhadap perceived risk

H3. Perceived risk berpengaruh positif terhadap purchase intention

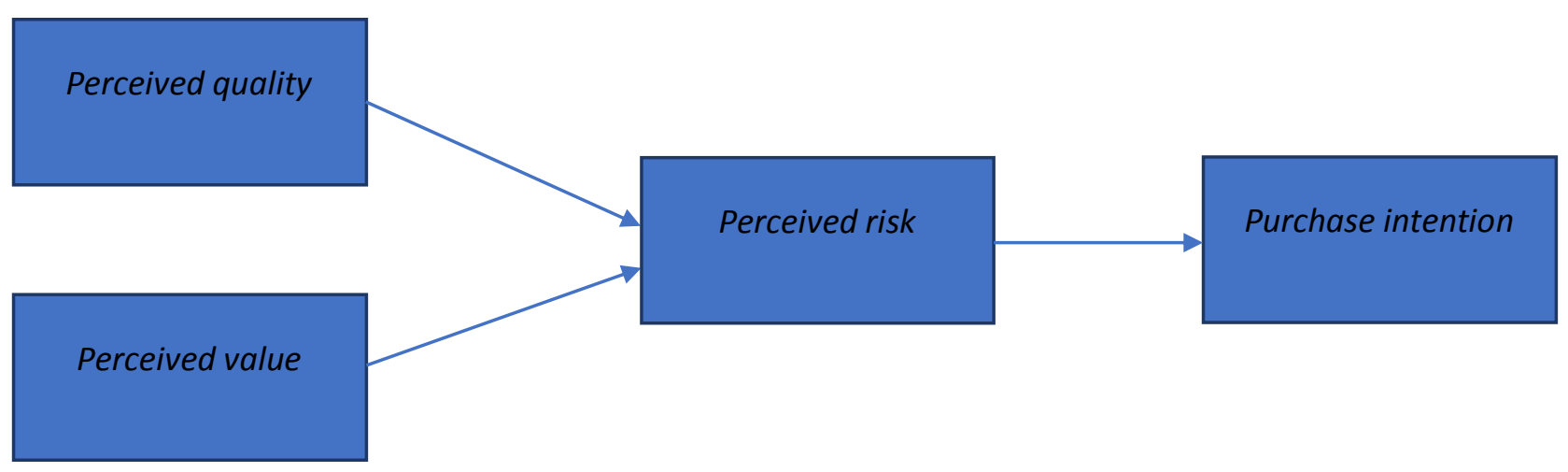




\section{METODOLOGI}

Menurut Nazir (2017) mengemukakan bahwa populasi adalah sekumpulan individu dengan karakter serta kualitas yang telah ditetapkan oleh seorang peneliti, adapun ciri atau kualitas tersebut yang mana hal itu dinamakan sebagai variabel. Populasi yang akan diambil pada penelitian ini adalah para pembeli dari produk OFFBEAT \& CO pada masyarakat Palembang, peneliti menggunakan populasi ini karena peneliti akan meneliti mengenai produk OFFBEAT \& CO. penelitian ini menggunakan OFFBEAT \& CO dikarenakan OFFBEAT \& CO merupakan salah satu merek yang terkenal di wilayah Palembang, dan sudah sangat dipercaya oleh masuarakat Palembang sehingga dapat mewakili atau menjelaskan sebagian besar variabel yang diteliti dalam penelitian ini.

Sampel merupakan bagian dari populasi yang dipilih sebagai partisipan dalam suatu penelitian. Penelitian ini menggunakan teknik pemilihan sampel tak acak (Non Probability Sampling) yaitu convenience sampling. Teknik pengambilan sampel ini berdasarkan pada ketersediaan elemen dan kemudahan untuk mendapatkannya. sampel dipilih karena ada pada tempat dan waktu yang tepat. Peneliti menggunakan teknik pemilihan sampel ini dikarenakan penelitian ini berfokus kepada OFFBEAT \& CO, dan akan menggunakan pembelinya dalam penelitian ini.

Kriteria dari responden di dalam penelitian ini adalah:

1. Responden merupakan pelanggan dari OFFBEAT \& CO

2. Responden merupakan pelanggan baru ataupun lama

3. Responden sudah berumur lebih dari 17 tahun

Menurut Arikunto (2016), Sampel adalah sebagian atau sebagai wakil populasi yang akan diteliti. Jika penelitian yang dilakukan sebagian dari populasi maka bisa dikatakan bahwa penelitian tersebut adalah penelitian sampel dan menurut Roscoe dalam (Sugiyono, 2016) mengatakan bahwa ukuran sampel yang layak digunakan dalam suatu penelitian adalah antara 30 sampai dengan 500 sampel dan bila dalam penelitian yang dilakukan peneliti menggunakan analisis dengan multivariate (korelasi atau regresi ganda), maka jumlah ukuran anggota sampel harus minimal 10 kali dari jumlah variabel yang diteliti. Variabel yang digunakan dalam penelitian ini adalah empat variabel, sehingga minimal sampel yang digunakan adalah 40 . Jumlah sampel yang digunakan dalam penelitian ini adalah adalah 100

\section{Hasil Uji Statistik}

\section{Uji validitas}

Pada hasil validitas didapatkan semua angka pada setiap pernyataan $>0,5$ pada nilai outer loadings untuk setiap pernyataannya, dan didapatkan semua angka $>0,5$ pada nilai Average Variance Extracted / AVE maka semua pernyataan dan variabel yang digunakan sudah valid. Kemudian cross loadings juga lolos karena nilai yang dihasilkan antara indikator terhadap variabel latennya sendiri lebih besar dibandingkan nilai yang dihasilkan antara indikator terhadap variabel laten lainnya.

\section{Uji reliabilitas}

Pada hasil reliabilitas, maka berdasarkan hasil yang dikalkulasi oleh program SmartPLS 3, didapatkan semua angka pada nilai Cronbach's Alpha dan Composite Reliability untuk setiap pernyataannya adalah $>0,6$. Maka pernyataan yang digunakan dalam penelitian ini sudah reliabel berdasarkan kedua nilai reliabilitas, yakni Cronbach's Alpha dan Composite Reliability. 


\section{Pengujian konstruk penelitian}

$\mathrm{R}^{2}$ variabel perceived risk adalah 0.425 sehingga dapat dijelaskan bahwa sebesar $43 \%$ dipengaruhi oleh variabel perceived quality dan perceived value, sedangkan sisanya $57 \%$ dapat dijelaskan oleh variabel-variabel lain di luar variabel didalam penelitian ini. Selain itu, $\mathrm{R}^{2}$ variabel purchase intention adalah 0.220 sehingga dapat dijelaskan bahwa sebesar $22 \%$ dipengaruhi oleh variabel perceived risk, sedangkan sisanya $78 \%$ dipengaruhi oleh variabel lain. Dengan demikian, nilai $\mathrm{R}^{2}$ pada penelitian ini dikategorikan subtantial (sedang)

Tabel 2

\section{Hasil Pengujian Hipotesis}

\begin{tabular}{|l|l|l|l|l|l|}
\hline Variable & $\begin{array}{l}\text { Path } \\
\text { coefficients }\end{array}$ & $\begin{array}{l}\text { Sample } \\
\text { Mean } \\
(\mathrm{M})\end{array}$ & $\begin{array}{l}\text { Standard } \\
\text { Deviation } \\
\text { (STDEV) }\end{array}$ & $\begin{array}{l}\text { T Statistics } \\
(|\mathrm{O} / \mathrm{STDEV}|)\end{array}$ & P Values \\
\hline $\begin{array}{l}\text { Perceived } \\
\text { quality } \rightarrow \\
\text { perceived } \\
\text { risk }\end{array}$ & 0.254 & 0.254 & 0.114 & 2.220 & 0.027 \\
\hline $\begin{array}{l}\text { Perceived } \\
\text { risk } \rightarrow \\
\text { purchase } \\
\text { intention }\end{array}$ & 0.469 & 0.470 & 0.095 & 4.949 & 0.000 \\
\hline $\begin{array}{l}\text { Perceived } \\
\text { value } \rightarrow \\
\text { perceived } \\
\text { risk }\end{array}$ & 0.449 & 0.453 & 0.104 & 4.313 & 0.000 \\
\hline
\end{tabular}

\section{DISKUSI}

Hasil nilai $t$-statistics ditujukan untuk menguji hipotesis didalam penelitian, dimana hipotesis penelitian dapat diterima apabila nilai t-statistics variabel $>1,96$ (tingkat signifikansi $5 \%$ ) dan p-value $<0.05$ (5\%). Nilai t-statistics dan p-value ini dapat dilihat dimasing-masing hipotesis yang terlampir pada tabel 4.14 (Hasil Bootstrapping).

a. Hipotesis 1

\section{H1 : perceived quality berpengaruh positif terhadap perceived risk}

Hipotesis pertama membahas mengenai pengaruh dari perceived quality terhadap perceived risk. Nilai t-statistics untuk hipotesis pertama 2.220 (t-statistics $>1,96$ ) dan nilai p-value sebesar 0,027 ( $\mathrm{p}<0,05)$, sehingga hasil hipotesis pertama diterima. Dengan demikian, perceived quality berpengaruh positif dan signifikan terhadap perceived risk

\section{b. Hipotesis 2}

H2 : perceived value berpengaruh positif terhadap perceived risk

Hipotesis kedua membahas mengenai hasil perceived value terhadap perceived risk. Nilai tstatistics untuk hipotesis kedua adalah 4.313 (t-statistics $>1,96$ ) dan nilai p-value sebesar $0,000(\mathrm{p}<0,05)$, sehingga hasil hipotesis kedua diterima. Dengan demikian, perceived quality berpengaruh positif terhadap perceived risk. 


\section{c. Hipotesis 3}

\section{H3: perceived risk berpengaruh positif terhadap purchase intention}

Hipotesis ketiga membahas mengenai perceived risk terhadap purchase intentioni. Nilai tstatistics untuk hipotesis ketiga adalah 4.949 (t-statistics $>1,96)$ dan nilai $p$-value sebesar $0.000(\mathrm{p}<0,05)$, sehingga hasil hipotesis ketiga diterima. Dengan demikian, dapat dketahui bahwa perceived risk berpengaruh positif terhadap purchase intention

\section{Penutup}

\section{Kesimpulan}

1. Perceived quality berpengaruh positif dan signifikan terhadap perceivd risk

2. Perceived value berpengaruh positif dan signifikan terhadap perceived risk

3. Perceived risk berpengaruh positif dan signifikan terhadap purchase intention

\section{Saran}

Saran yang akan diajukan pasca proses penelitian ini ditujukan untuk dapat memajukan kualitas proses penelitian khususnya dengan model penelitian yang sama. Maka dalam penelitian ini dapat diuraikan saran sebagai berikut :

a. Teoritis

Berdasarkan hasil yang didapat, diketahui perceived quality, perceived value berpengaruh positif dan signifikan terhadap perceived risk, dan perceived risk berhubungan positif dan signifikan terhadap purchase intention, sehingga berdasarkan hasil penelitian ini maka OFFBEAT \& CO dapat memperhatikan mengenai perceived value, perceived quality dan perceived risk di dalam meningkatkan purchase intention, sehingga akan dapat membantu penjualan lebih tinggi kembali dan juga daoat lebih mengetahui persepsi setiap pelanggan yang akan mengakibatkan peningkatan dari purchase intention

\section{b. Praktis}

Penelitian ini masih belum sempurna, karena itu diharapkan bagi para peneliti selanjutnya diharapkan turut mempertimbangkan variabel-variabel lainnya yang dapat memprediksi dari purchase intention. Selain itu diharapkan peneliti selanjutnya dapat menambah variabel dalam penelitian, menambah responden sebagai alat ukur untuk kuesioner sehingga dapat memberikan banyak kesimpulan bagi perusahaan sebagai dasar untuk masukan dalam meningkatkan purchase intention

\section{DAFTAR PUSTAKA}

Aaker dan Biel. 1993. Brand Equity and Advertising : Advertising's Role in Building Strong Brand.

Angipora, Marius. 2002. Dasar-Dasar Pemasaran. Edisi Kedua. PT. Raja Grafindo Persada. Jakarta

ed.). Roudledge.

Creswell, J. . (2008). Educational Research: Planning, Conducting, and Evaluating Quantitative and Qualitative Research. Pearson Merrill Prentice Hall.

Djaslim Saladin, 2001, "Manajemen Pemasaran, Analisis, Perencanaan, Pelaksanaan dan Pengendalian". Penerbit :Lindakarya, Bandung.

Ghozali, I. (2016). Aplikasi Analisis Multivariete Dengan Program. In IBM SPSS 23 (8th ed.). Badan Penerbit Universitas Diponegoro.

Hair, Joseph E, J. et al. (2014). A Primer on Partial Least Squares Structural. Equation 
Modelling (PLS-SEM). SAGE Publications,Inc.

Hair, J. et. a. (2010). Multivariate Data Analysis (7th ed.). Pearson.

Hakim LL, Keni. (2020). Pengaruh Brand Awareness, Brand Image dan Customer Perceived Value Terhadap Purchase Intention. 4(3);81-86.

Keller, K.L. (1993) Conceptualizing, Measuring, and Managing Customer-Based Brand Equity. Journal of Marketing, 57, 1-22.

Kotler, Philip., Armstrong,G. 2008, Prinsip-prinsip Pemasaran, Edisi 12 Jilid 1. Erlangga, Jakarta.

Kotler, Philip.2012.marketing manajemen/ Philip kotler,Kevin Lane Keller,- 14thed

Kotler, Philip and Gary Armstrong. 2012. Prinsip-prinsip Pemasaran. Edisi. 13. Jilid 1. Jakarta: Erlangga.

Kotler, Philip, 2002, Manajemen Pemasaran, Jilid II, Edisi Milenium, PT. Prenhallindo, Jakarta.

Kartajaya, Hermawan , 2004, Markplus on Strategy, PT. Gramedia Pustaka Utama, Jakarta

Kurniawan, Agnes, 2007, Honda VS Honda, agneskurniawan.wordpress.com diakses Rabu 10 Desember 2008.

Mahmoudzadeh, S. M., Bakhshandeh, G., \& Ilkhechi, M. S. (2014). Exploring the effect of Brand Identity on Purchase Intention in Cell Phone Market in Iran. Management and Humanity Sciences, 1165-1173.

Nazir. (2014). Metode Penelitian. Ghalia Indonesia.

Shah et al. (2012). Factors affecting Pakistans University Students Purchase Intention Towards Foreign Apparel Brands. Journal of Management 17(1;1-14).

Tjiptono, Fandy. 2006. Manajemen Jasa. Edisi Keempat. Andi. Yogyakarta.

Tjiptono, Fandi, Chandra.G. 2012. Pemasaran Strategik, Edisi 2, Andi Offset, Yogyakarta. 